\title{
COMUNICACIÓN
}

\section{Genotyping of Toxoplasma gondii strains detected in pork sausage}

\author{
ARISTEU VIEIRA DA SILVA*,***, ANDRÉ DE OLIVEIRA MENDONÇA**, SANDIA BERGAMASCHI \\ PEZERICO***, PAULO FRANCISCO DOMINGUES*** and HELIO LANGONI***
}

\begin{abstract}
DNA was extracted from 70 pork sausage samples obtained from 55 commercial establishments in the city of Botucatu, Sao Paulo, Brazil. Nested-polymerase chain reaction with primers specific for Toxoplasma gondii SAG2 locus was used and detected the parasite in 19 (27.14\%) sausage samples. Digestion of amplicons with restriction enzymes HhaI and Sau3AI showed that $14(73.68 \%)$ samples contained parasites genotyped as Type I, and 5 (26.32\%) as Type III.
\end{abstract}

Key words: Toxoplasma gondii; SAG2 genotyping; food-borne pathogen; sausage; swine.

\section{INTRODUCTION}

Toxoplasmosis is a worldwide-distributed zoonosis caused by the protozoan Toxoplasma gondii. This parasite presents a highly clonal populational structure ${ }^{1}$ made up of three lineages, Types I, II and III. Several reports genetically classified strains of $T$. gondii isolated from humans ${ }^{2-5}$. However, there are few reports on the genotyping of $T$. gondii obtained from domestic animals.

Different strains of the parasite may be better adapted to several intermediate hosts ${ }^{6}$. Epidemiological surveillance is important to analyze greater collection of $T$. gondii strains from multiple sources of infection, in order to evaluate possible associations between parasite Types and severity of the disease in humans and animals ${ }^{7,8} \cdot T$. gondii infection generally is not a problem for healthy individuals, but congenitallyinfected people, immunosupressed and AIDS patients may develop important lesions ${ }^{9}$.

Meat-producing animals can be infected with T. gondii $^{10}$, but pork was considered as the most important source of $T$. gondii for humans in some countries ${ }^{11}$. In Brazil, as in other countries, technical improvement in swine meat production led to a reduction of $T$. gondii prevalence in young pigs ${ }^{12}$. However, it has been pointed out that older animals show higher prevalence of the parasite ${ }^{13}$, and these animals are frequently used for the production of sausages, salami and cured

\footnotetext{
* Universidade Paranaense (UNIPAR). Praça Mascarenhas de Moraes, s/n, 87.502-210, Umuarama, Paraná, Brazil.

** Laboratório Regional de Apoio Animal, Ministério da Agricultura, Pecuária e Abastecimento. Rua Raul Ferrari, s/ n, 13.094-430, Campinas, São Paulo, Brazil.

***Núcleo de Pesquisa em Zoonoses (NUPEZO), Departamento de Higiene Veterinária e Saúde Pública (DHVSP), Faculdade de Medicina Veterinária e Zootecnia (FMVZ), Universidade Estadual Paulista (UNESP), Campus Botucatu. Distrito de Rubião Jr., s/n, 18.610-000, Botucatu, São Paulo, Brazil.

Corresponding author: Tel: 554436225126 - fax: 554436225126 - e-mail address: silva.av@uol.com.br
} 
meats, with potential risk of human infection after the intake of these foodstuffs 9 .

The objective of the present trial was to evaluate the genotypes of $\mathrm{T}$. gondii strains in fresh pork sausage samples obtained in Botucatu, Sao Paulo, Brazil.

\section{MATERIALS AND METHODS}

Fresh pork sausage samples: Seventy fresh pork sausage samples (weighting at least $50 \mathrm{~g}$ each) were collected from 55 commercial establishments in the city of Botucatu-SP. Samples were identified and transported under refrigeration to the NUPEZO (Núcleo de Pesquisas em Zoonoses / Center of Research in Zoonoses) laboratory, where they were analyzed. Previous trial ${ }^{14}$ showed that none of these parasites were isolated in mice; probably, salt content of these sausages kill $T$. gondii present in the samples, making it impossible to isolate the parasite and conduct pathogenicity studies.

DNA extraction from sausage samples: In order to concentrate de parasite in each sample, sausages ( $20 \mathrm{~g}$ each) were cut in to small pieces, ground in a blender with $100 \mathrm{ml}$ of normal saline solution $(0.85 \% \mathrm{NaCl})$. Tissue homogenate was mixed with $100 \mathrm{ml}$ of acidic pepsin and incubated for $1 \mathrm{~h}$ at $37^{\circ} \mathrm{C}$, centrifuged and neutralized ${ }^{15}$. The pellet was resuspended to a final volume of $5 \mathrm{ml}$ with TNE buffer ( $200 \mathrm{mM} \mathrm{NaCl}, 20 \mathrm{mM}$ Tris, $50 \mathrm{mM}$ EDTA), and DNA was extracted by digestion with proteinase K and SDS, followed by purification with phenol-chloroform and precipitation with ethanol ${ }^{16}$. Briefly, $250 \mathrm{ml}$ samples of digested sausages were homogenized using $250 \mathrm{ml}$ extraction buffer (TNE buffer plus proteinase $\mathrm{K} 1 \mathrm{mg} / \mathrm{ml}$ and $2 \% \mathrm{SDS}$ ) and incubated at $56^{\circ} \mathrm{C}$ for $1 \mathrm{~h}$. Buffered phenol $(500$ $\mathrm{ml}$ ) was added and the samples were centrifuged at $13,000 \mathrm{~g}$ for $3 \mathrm{~min}$. Resulting aqueous layer was transferred to another microtube, added to phenol: chloroform:isoamyl alcohol, homogenized, and centrifuged at 13,000 $\mathrm{g}$ for other 3 min. Resulting aqueous layer was transferred to another microtube, mixed with $36 \mathrm{ml}$ of $2 \mathrm{M}$ sodium acetate and $472 \mathrm{ml}$ of cold ethanol, and stored at $-20^{\circ} \mathrm{C}$ for $16-24 \mathrm{~h}$. Samples were then centrifuged at $13,000 \mathrm{~g}$ for $10 \mathrm{~min}$, added of 470 $\mathrm{ml}$ of cold ethanol, and centrifuged again at $13,000 \mathrm{~g}$ for $10 \mathrm{~min}$. DNA samples were resuspended in $50 \mathrm{ml}$ of ultra-pure water, incubated at $56^{\circ} \mathrm{C}$ for $30 \mathrm{~min}$, and stored at $20^{\circ} \mathrm{C}$ until PCR was to be performed.

SAG2 typing of sausage samples: DNA samples were submitted to nested PCRs for the 3' and 5'ends of SAG2 gene $^{4}$, followed by digestion with restriction enzymes Sau3AI e Hha1, respectively. Initially PCR and nested PCR were performed in a thermal cycler (Biorad) in $50 \mathrm{ml}$ samples placed in microtubes containing $50 \mathrm{mM}$ $\mathrm{KCl}, 10 \mathrm{mM}$ Tris- $\mathrm{HCl}, 1.5 \mathrm{mM} \mathrm{MgCl}, 1.25 \mathrm{mM}$ dNTPs, 1.5 units of Taq-polymerase, $10 \mathrm{ml}$ of extracted DNA (PCR) or $1 \mathrm{ml}$ of amplicom (nested PCR), water to $50 \mathrm{ml}$, and $10 \mathrm{pM}$ of the primers SAG2.F4 and SAG2.R4 (PCR for the 3' end), SAG2.F and SAG2.R2 (nested PCR for the 3'end), SAG2.F3 and SAG2.R3 (PCR for the 5'end), and SAG2.F2 and SAG2.R (nested PCR for the 5'end). Two rounds of 35 amplification cycles were performed for $30 \mathrm{~s}$ at $94^{\circ} \mathrm{C}, 60 \mathrm{~s}$ at $63^{\circ} \mathrm{C}$ ( $3^{\prime}$ end $)$ or $65^{\circ} \mathrm{C}$ (5'end), and $60 \mathrm{~s}$ at $72^{\circ} \mathrm{C}$. Seven $\mathrm{ml}$ of each amplicom was digested with $1 \mathrm{ml}$ of restriction enzymes Sau3AI e Hha1, for nested PCR to 3' and 5' ends, respectively, for 2 hours at $37^{\circ} \mathrm{C}$. Fragments were detected in $1.5 \%$ agarose gel electrophoresis stained with ethidium bromide. RH, ME49, and M7741 strains of T. gondii were used as controls for Types I, II and III, respectively. Water negative control templates were added to each batch of PCR and nested PCR assays. The risk of contamination was minimized by the use of different locations in each phase of molecular analysis, and by the use of small amounts of reagents and disposable labware.

\section{RESULTS AND DISCUSSION}

T. gondii DNA was found in $19(27.14 \%)$ of 70 sausage samples examined. Nested-PCR for 3 ' and 5' ends of SAG2 gene demonstrated that after digestion of the amplicons with enzymes Sau3AI and HhaI, 14 (73.68\%) and 5 (26.32\%) samples presented Type I and Type III parasites, respectively.

Only few other studies reported genotypes of $T$. gondii from pig or pig products. In one of them, in 43 strains isolated from adult sows from Iowa, USA, was found 36 Type II strains and 7 Type III strains ${ }^{7}$, and in other one it was found in 25 isolates from market age pigs, that 20 were type III and five were type II ${ }^{17}$. Other authors, found $20(34.48 \%)$ samples positive 
for $T$. gondii DNA among 58 meat products containing pork meat in the United Kingdom, with $17(85.00 \%)$ SAG2 Type I samples and 3 $(15.00 \%)$ mixed SAG2 Type I + II samples ${ }^{9}$, probably due the mixing of meat from different animals in the same product.

These results demonstrated the difference on the genetic distribution of $T$. gondii in different geographic regions. In the present trial, no Type II strain was found, and Type I was the most prevalent one. Dubey et $\mathrm{al}^{18}$ found only Type I and Type III $T$. gondii in brain and heart samples of poultry from Brazil, and three of these samples were from Botucatu, the same site of our study. In other two studies with samples from Brazil, it was found only Type I and Type III strains in poultry, and in one sample, mixed Type I+III infection was observed, confirming the differences on genetic distribution of the parasite in North America, the United Kingdom and Brazil $^{19,20}$. Of 37 isolates of viable T. gondii found in Paraná, Brazil, 22 were type III and 15 were type $\mathrm{I}^{21}$.

Another interesting finding was that some Type III isolates from poultry in Brazil are virulent to mice in primary isolation ${ }^{19}$, a result that is in disagreement with other trials, where SAG2 Type III T. gondii was found to be non-virulent to mice $^{22}$. In our trial with strains from pork sausage, it was not possible isolate the parasite in order to conduct virulence studies ${ }^{14}$. However, in the study of $T$. gondii strains isolated from dogs in the same city ${ }^{23}$, five Type III strains were found, and all of them killed all four mice inoculated, in a period ranging from 5 to 20 days. Further studies should be conducted in order to evaluate the extension of genetic differences between samples classified as Type III in the United States and in Brazil, as well as a possible relationship between their clinical behavior.

In spite of the decrease in the prevalence of the infection in pigs due to large scale technification in swine production, many regions in Brazil still have small, familiar breeding units, where sanitary conditions and direct contact with other animals ands men enable the maintenance of T.gondii. Thus, typing and virulence studies using $T$. gondii samples may contribute for the production of a clearer picture in relation to the distribution of different parasite clones between human and animal populations ${ }^{8}$.
The present study describes the first genotyping of $T$. gondii DNA detected in pig samples in Brazil.

\section{RESUMEN}

Se extrajo el ADN de muestras de chorizo de cerdo obtenidas de 55 establecimientos comerciales en la ciudad de Botucatu, Sao Paulo, Brasil. Se utilizó la reacción de polimerasa en cadena (PCR) en un ensayo con oligonucleotideos específicos para el locus SAG2 de Toxoplasma gondii, en el cual se detectó el parásito en 19 $(27,14 \%)$ de las muestras de chorizo. La digestión de los amplificados con las enzimas de restricción HhaI y Sau3AI demostró que 14 muestras (73,68\%) tenían cepas de $T$. gondii Tipo I y 5 $(26,32 \%)$ del Tipo III.

\section{REFERENCES}

1.- HOWE D K, SIBLEY L D. Toxoplasma gondii comprises three clonal lineages: correlation of parasite genotype with human disease. J Infect Dis 1995; 172: 1561-6.

2.- DARDE M L, BOUTEILLE B, PESTRE-ALEXANDRE M. Isoenzyme analysis of 35 Toxoplasma gondii isolates and the biological and epidemiological implications. J Parasitol 1992; 78: 786-94.

3.- HOWE D K, HONORE S, DEROUIN F, SIBLEY L D, Determination of genotypes of Toxoplasma gondil strains isolated from patients with toxoplasmosis. J Clin Parasitol 1997; 35: 1411-4.

4.- HONORÉ S, COUVELARD A, GARIN Y J F, et al Génotypage de souches de Toxoplasma gondii chez des patients immunodéprimés. Pathol Biol 2000; 48: 541-7.

5.- FUENTES I, RUBIO J M, RAMIREZ C, ALVAR J, Genotypic characterization of Toxoplasma gondii strains associated with human toxoplasmosis in Spain: direct analysis from clinical samples. J Clin Microbiol 2001; 39: 1566-70.

6.- LEHMANN T, BLACKSTON C R, PARMLEY S F, et al. Strain typing of Toxoplasma gondii: comparison of antigen-coding and housekeeping genes. J Parasitol 2000; 86: 960-71.

7.- MONDRAGON R, HOWE D K, DUBEY J P, SIBLEY L D. Genotypic analysis of Toxoplasma gondii isolates from pigs. J Parasitol 1998; 84: 639-41.

8.- OWEN M R, TREES A J. Genotyping of Toxoplasma gondii associated with abortion in sheep. J Parasitol 1999; 85: 382-4.

9.- ASPINALL T V, MARLEE D, HYDE J E, SIMS P F G. Prevalence of Toxoplasma gondii in commercial meat products as monitored by polymerase chain reaction food for thought? Int J Parasitol 2002; 32: 1193-9.

10.- TENTER A M, HECKEROTH A R, WEISS L M, Toxoplasma gondii: from animals to humans. Int $\mathbf{J}$ 
Parasitol 2000; 30: 1217-58.

11.- DUBEY J P. Toxoplasmosis. J Am Vet Med Assoc 1994; 205: 1593-8.

12.- DA SILVA A V, CAPORALI E H G, LANGONI H, Estudo epidemiológico da toxoplasmose em granjas de suínos dos Estados de São Paulo e Pernambuco. Arq Ciên Vet Zool UNIPAR 2003; 6: 204.

13.- DUBEY J P. Sources of Toxoplasma gondii infection in pregnancy. Until rates of congenital falls, control measures are essencial. Br Med J 2000; 321: 127-8.

14.- MENDONÇA A O, DOMINGUES P F, DA SILVA A $\mathrm{V}$, et al. Detection of Toxoplasma gondii in swine sausages. Parasitol Panam 2004; 59 (in press).

15.- DUBEY J P. Refinement of pepsin digestion method for isolation of Toxoplasma gondii from infected tissues. Vet Parasitol 1998; 74: 74-7.

16.- DA SILVA A V, LANGONI H. The detection of Toxoplasma gondii by comparing cytology, histopathology, bioassay in mice, and the polymerase chain reaction (PCR). Vet Parasitol 2001; 97: 191-8.

17.- LEHMANN T, GRAHAM D H, DAHL E. Transmission dynamics of Toxoplasma gondii on a pig farm. Infect Gen Evol 2003; 3: 135-41.

18.- DUBEY J P, GRAHAM D H, BLACKSTON C R, et al. Biological and genetic characterisation of Toxoplasma gondii isolates from chickens (Gallus domesticus) from São Paulo, Brazil: unexpected findings. Int $\mathbf{J}$ Parasitol 2002; 32: 99-105.

19.- DUBEY J P, GRAHAM, D.H., SILVA, D.S., et al.,.
Toxoplasma gondii isolates of free-ranging chickens from Rio de Janeiro, Brazil: mouse mortality, genotype, and oocyst shedding by cats. J Parasitol 2003a; 89: 851-3.

20.- DUBEY J P, NAVARRO I T, GRAHAM D H, et al. Characterization of Toxoplasma gondii isolates from free range chickens from Paraná, Brazil. Vet Parasitol 2003b; 117: 229-34.

21.- DUBEY J P, NAVARRO I T, SREEKUMAR C, et al. Toxoplasma gondii infections in cats from Parana, Brazil: seroprevalence, tissue distribution, and biologic and genetic characterization of isolates. J Parasitol 2004; 90: 721-6.

22.- BOOTHROYD J C, GRIGG M E. Population biology of Toxoplasma gondii and its relevance to human infection: do different strains cause different disease? Curr Op Microbiol 2002; 5: 438-42.

23.- DA SILVA A V, PEZERICO S B, DE LIMA V Y, et al. Genotyping of Toxoplasma gondii strains isolated from dogs with neurological signs. Vet Parasitol 2005; 127: 23-7.

Acknowledgments: The authors would like to thank Fundação de Apoio a Pesquisa do Estado de São Paulo FAPESP (00/00418-5, 01/12052-8 and 01/10275-0) and Fundação para o Desenvolvimento da UNESP FUNDUNESP (427/2001) for the financial support, and Universidade Paranaense - UNIPAR for Doctor's degree Research Grant to Aristeu Vieira da Silva.

\title{
MEDICINE AND HEALTH IN THE TROPICS Marseille - France 11 - 15 September 2005
}

\author{
XVIth International Congress for Tropical Medicine and Malaria
}

IVth European Congress on Tropical Medicine and International Health

VII ${ }^{e}$ Congrès International de la Socièté de Pathologie Exotique

Centenaire de L'Institut de Médicine Tropicale du Service de Santè des Armèes 